\title{
Study on Relative Preferences of Foliar Nematode, Aphelenchoides besseyi Christie between Rice and Tuberose on Biochemical Factors
}

\author{
Nagulapalli Sneha Latha*, Ajoy Kumar Mukhopadhyay, Nagamandla Ramya Sri, \\ Nihal Ravindranath and Dhiren Chatterjee
}

\author{
Bidhan Chandra Krishi Viswavidhyalaya, Faculty of agriculture, Mohanpur, Nadia, \\ West Bengal, 741252, India \\ *Corresponding author
}

\section{A B S T R A C T}

\begin{tabular}{|l|}
\hline Ke y w o r d s \\
$\begin{array}{l}\text { Aphelenchoides } \\
\text { besseyi, Foliar } \\
\text { nematodes, } \\
\text { Comparative } \\
\text { preference, Protein, } \\
\text { carbohydrate, Silicon. }\end{array}$ \\
\hline Article Info \\
\hline $\begin{array}{l}\text { Accepted: } \\
\text { 14 September } 2017 \\
\text { Available Online: } \\
\text { 10 October } 2017\end{array}$ \\
\hline
\end{tabular}

From early 90s we have been observing that Aphelenchoides besseyi also, to affect tuberose badly in West Bengal as well as in other tuberose growing adjacent states. Interestingly, in most of the cases where tuberose is grown side by side or in sequence with rice, manifestation of symptoms is seen only in tuberose but not in rice. This made us curious to search the reasons behind, comparative preference of nematodes towards tuberose. We decided to go for biochemical analysis of both the plants. The experiment was carried out in the field from 2016 - 2017 at Central research farm of B.C.KV, Gayeshpur, W.B and Laboratory experiment done at college of agriculture at B.C.K.V, Mohanpur. Results of this experiment showed that, total protein, carbohydrate contents were found to be higher and silicon content was found to be lower in Tuberose when compared to rice, as protein and carbohydrate are essential for the nematode for its growth and development. Silicon helps to strengthen cells of rice leaf, stem, and roots. Silicon confers resistance to herbivores via physical and biochemical. Therefore, differential contents of these facets could have been a strong reason behind the inclination of preference to tuberose by the foliar nematodes.

\section{Introduction}

Among the ornamental bulbous plants, "Tuberose (Polianthes tuberosa)" popularly known as "Rajanigandha" which is valued much by the aesthetic world for beauty and fragrance of their flowers, elegance and sweet pleasant for cut-flower trade and essential oil industry. They are used for artistic garlands, floral ornaments, bouquets and buttonholes. The long flower spikes are excellent as cut flowers for table, stripes leaf margins is very attractive and suitable for the beautification of gardens. The flower possesses aromatic oil which is the source of its delightful fragrance.
The natural flower oil of tuberose remains today one of the most expensive of the perfumer's raw materials. Tuberose is a quite hardy plant, although many pests were recorded feeding in these flower crops. Among these pests, one of the most important pest was recorded is Aphelenchoides besseyi (Foliar nematode). The foliar nematode, Aphelenchoides besseyi was first time reported from leaves of tuberose in the Hawaii Island by Holtzmann (1968) known to cause 'Floral malady'. Market value of flower is highly reduced due to reduction of 
fragrance and change the colour of flower. It has been also identified as the key pest and is posing a serious threat to the "Rice (Oryza sativa") which is essential for our day to day life and serves as the most important food source for Asian countries where it is an economic crop for farmers and workers who grow it on millions of hectares throughout the region. Dastur (1936) first time reported Aphelenchoides besseyi Christie on rice. This nematode known to cause 'white tip' diseases of rice has been found in upland and irrigated rice in many rice growing countries. The estimated rice yield reduction in India due to rice white tip nematode is 14.5 to $71 \%$ (Rao et al., 1985).From early 90s we have been observing that Aphelenchoides besseyi also, to affect tuberose badly in West Bengal as well as in other tuberose growing adjacent states.

Interestingly, in most of the cases where tuberose is grown side by side of rice or in sequence with rice, manifestation of symptoms is seen only in tuberose but not in rice. Here, the nematodes either do not attack rice to that extent which could lead to symptom manifestation or if the tiny organisms are recovered from the rice seeds, the plants remain without apparent infestation. This made us curious to search the reasons behind this comparative preference of the nematodes towards tuberose. We decided to go for biochemical analysis of both the plants so that the nematodes' preference or non-preference could be clarified based on the biochemical facets.

\section{Materials and Methods}

The experiment was carried out from 2016 2017 at Central research farm of Bidhan Chandra Krishi Viswavidyalaya, Gayeshpur, Nadia, West Bengal. Laboratory experiment for protein, carbohydrate and silica estimation was done at Bidhan Chandra Krishi Viswavidyalaya, Mohanpur.
Collection of the flower sample for nematode inoculation in rice plants. Nematode infested flower samples of Calcutta double of tuberose were collected randomly from fixed plots and brought to the laboratory for extraction of nematodes by the Cobbs Sieving and decanting method and modified Baermann funnel technique (Southey, 1970).Estimation of nematode in samples and counting of population of the nematode were done. From thoroughly stirred suspension, $2 \mathrm{ml}$ was drawn with the help of pippete and taken on counting disc for counting the nematodes under stereoscopic binocular microscope. Then average number of nematode for $2 \mathrm{ml}$ of suspension was determined.

Planting of Semi-dwarf rice variety Satabdi (IET-4786). Tuberose varieties of (Calcutta double and Calcutta single) Bulbs infested with nematode were presoaked overnight and planting was done. After initiation of rice flower, nematode inoculation were done (2ml/plant) with the help of syringe in between the leaf and the flower initiated, at 10 days interval for 3 times.

During the programme, tuberose and rice plants were examined thoroughly to see any changes in colour, texture, characteristics of the leaves, floral scape, flower of tuberose and seed, leaf and culm of rice. Collection of the flower and mature rice seed sample for the estimation of population. Nematode infested flower samples of $20 \mathrm{~g}$ and rice $10 \mathrm{gm}$ seed were collected randomly from fixed plots and brought to the laboratory for extraction of nematodes by the Cobbs Sieving and decanting method and modified Baermann funnel technique (Southey, 1970). Killing (Water Bath Method) and fixing at temp $60^{\circ} \mathrm{C}$.Subsequently, the killed nematode were fixed by adding equal volume of $4 \%$ formaldehyde and were kept separately in the labeled plastic bottle for further study. Counting of nematodes under stereoscopic 
binocular microscope. Then average number of nematode for $2 \mathrm{ml}$ of suspension was determined.

After the examinations the infected tuberose plant parts (scape and flowers) and rice (seed and culm) were collected randomly for the further examination in terms of biochemical contents like Changes in total protein, sugar and silica levels were estimated by the methods (Lowry et al., 1951) and Anthrone method and by Hessey respectively. Statistical significance of the means was analyzed by ANOVA.

\section{Results and Discussion}

Over 67 different crops including maize, chrysanthemum and oat are attacked by Aphelenchoides besseyi Christie, among them rice, strawberry and tuberose are the principal hosts in India. The A. besseyi population from tuberose was proven earlier to be the same population causing white tip disease of rice (Khan, 2001). Plant- nematode interactions could be interpreted based on biochemical analysis of either one or both the interacting organisms. Many biochemical factors are known to be associated with biotic resistance in crop plants and it is obvious that the biochemical factors are more important than morphological and physiological factors in conferring non preference and antibiosis (Prabhu et al., 2008).

Tuberose flowers and stalk, rice seeds and culms were collected randomly from the experimental field. Infestation by the foliar nematodes was ascertained through extraction of nematodes from the tuberose flowers and rice seeds respectively.

The population of foliar nematodes in flowers of Calcutta double variety of tuberose was found to be approximately 5,152/20gm whereas that in the flowers of Calcutta single variety found to be approximately 600 nematodes/20gm. The population of foliar nematodes recovered from the seeds of rice variety Satabdi (IET-4786) was 90/10g of seeds.

\section{Plant protein profile}

Experimental results on total protein differentiation of foliar nematode in uninfected tuberose and rice plants during 2016-2017 revealed that the total protein content was higher in tuberose uninfected flowers $(2.76 \%)$ than uninfected rice seeds $(1.47 \%)$. On the other hand, it was also observed that infected tuberose flowers contained more protein than uninfected ones. Protein is essential for the nematode for its growth, development and reproduction.

Nematodes' hydrolysing enzymes which they inject in the plant tissues for solubilising the tissue contents for subsequent feeding, are constituted of proteins. Nematodes also obtain many essential amino acids from their hosts. So more protein content in tuberose flowers or as such in tuberose plants could be a good reason for more preference to tuberose by the nematodes over rice. Now when the results were compared between infested and healthy tuberose plants we could find that the total protein was higher in infested plants than that of healthy plant parts.

This observation corroborated with the observation by Ravichandra (2008). In order to withstand the feeding and the biochemical change inside the plant tissue, more proteins might have been accumulated to increase the resistance in the plants.

Even the additional protein could have been a result of the release of the enzymes in the plant tissues by nematodes, as mentioned earlier, which could be ascertained only through suitable biochemical analysis (Table 1). 
Table.1 Total protiens content in tuberose and rice plant parts during 2016-17

\begin{tabular}{|c|c|c|c|c|c|c|c|}
\hline Treatments & $\%$ Protein & Treatments & $\%$ Protein & Treatments & \% Protein & Treatments & \% Protein \\
\hline TUF & 2.76 & TIF & 3.39 & TUIST & 1.19 & TIST & 1.49 \\
\hline RUISE & 1.47 & RISE & 1.11 & RUICU & 1.67 & RICU & 1.11 \\
\hline Sem \pm & 0.029 & Sem \pm & 0.072 & Sem \pm & 0.042 & Sem \pm & 0.041 \\
\hline $\mathbf{F}_{\text {(calculated) }}$ & 990.421 & $\mathbf{F}_{\text {(calculated) }}$ & 499.846 & $\mathbf{F}_{\text {(calculated) }}$ & 66.462 & $\mathbf{F}_{\text {(calculated) }}$ & 45.459 \\
\hline $\mathbf{F}_{\text {(tabulated) }}$ & 21.198 & $\mathbf{F}_{(\text {tabulated) }}$ & 21.198 & $\mathbf{F}_{\text {(tabulated) }}$ & 21.198 & $\mathbf{F}_{(\text {tabulated) }}$ & 21.198 \\
\hline $\begin{array}{l}\text { UF-Tuberose uni } \\
\text { UISE-Rice uninf } \\
\text { UIST-Tuberose } \\
\text { UICU- Rice unin }\end{array}$ & $\begin{array}{l}\text { cted flower } \\
\text { ed seed } \\
\text { fected stalk } \\
\text { ted culm }\end{array}$ & $\begin{array}{l}\text { TIF-Tubero } \\
\text { RISE-Rice } \\
\text { TIST - Tub } \\
\text { RICU- Rice }\end{array}$ & $\begin{array}{l}\text { ted flower } \\
\text { seed } \\
\text { fected stalk } \\
\text { d culm }\end{array}$ & & & & \\
\hline
\end{tabular}

Table.2 Total silica content in tuberose and rice plant parts during 2016-2017

\begin{tabular}{|c|c|c|c|c|c|c|c|}
\hline Treatments & \% Silica & Treatments & $\%$ Silica & Treatments & $\%$ Silica & Treatments & $\%$ silica \\
\hline TUF & 1.06 & TIF & 1.16 & TIST & 1.06 & TUIST & 1.23 \\
\hline RUISE & 4.06 & RISE & 5.33 & RICU & 8.3 & RUICU & 6.23 \\
\hline Sem \pm & 0.289 & Sem \pm & 0.319 & Sem \pm & 0.359 & Sem \pm & 0.180 \\
\hline $\mathbf{F}_{\text {(calculated) }}$ & 54.0 & $\mathbf{F}_{\text {(calculated) }}$ & 85.150 & $\mathbf{F}_{\text {(calculated) }}$ & 203.408 & $\mathbf{F}_{\text {(calculated) }}$ & 384.615 \\
\hline $\mathbf{F}_{\text {(tabulated) }}$ & 21.198 & $\mathbf{F}_{\text {(tabulated) }}$ & 21.198 & $\mathbf{F}_{\text {(tabulated) }}$ & 21.198 & $\mathbf{F}_{\text {(tabulated) }}$ & 21.198 \\
\hline $\begin{array}{l}\text { F-Tuberose unin } \\
\text { ISE-Rice uninfe } \\
\text {-Tuberose infect } \\
\text { E-Rice infected }\end{array}$ & $\begin{array}{l}\text { flower } \\
\text { sed } \\
\text { wer }\end{array}$ & $\begin{array}{l}\text { TUIST-Tub } \\
\text { RUICU- Ri } \\
\text { TIST - Tub } \\
\text { RICU-Rice }\end{array}$ & $\begin{array}{l}\text { infected stal } \\
\text { ected culm } \\
\text { fected stalk } \\
\text { culm }\end{array}$ & & & & \\
\hline
\end{tabular}


Table.3 Total carbohydrate content in anthers of tuberose and rice plants during 2016-2017

\begin{tabular}{|l|c|}
\hline Treatments & Total carbohydrate content $(\%)$ \\
\hline Tuberose anthers & 2.52 \\
\hline Rice anthers & 2.09 \\
\hline Sem \pm & 0.031 \\
\hline F $_{(\text {calculated) }}$ & 98.542 \\
\hline F $_{\text {(tabulated) }}$ & 21.198 \\
\hline
\end{tabular}

Fig.1 Percentage changes in protein content in uninfected and infected plants of tuberose (flower) and rice (seed)

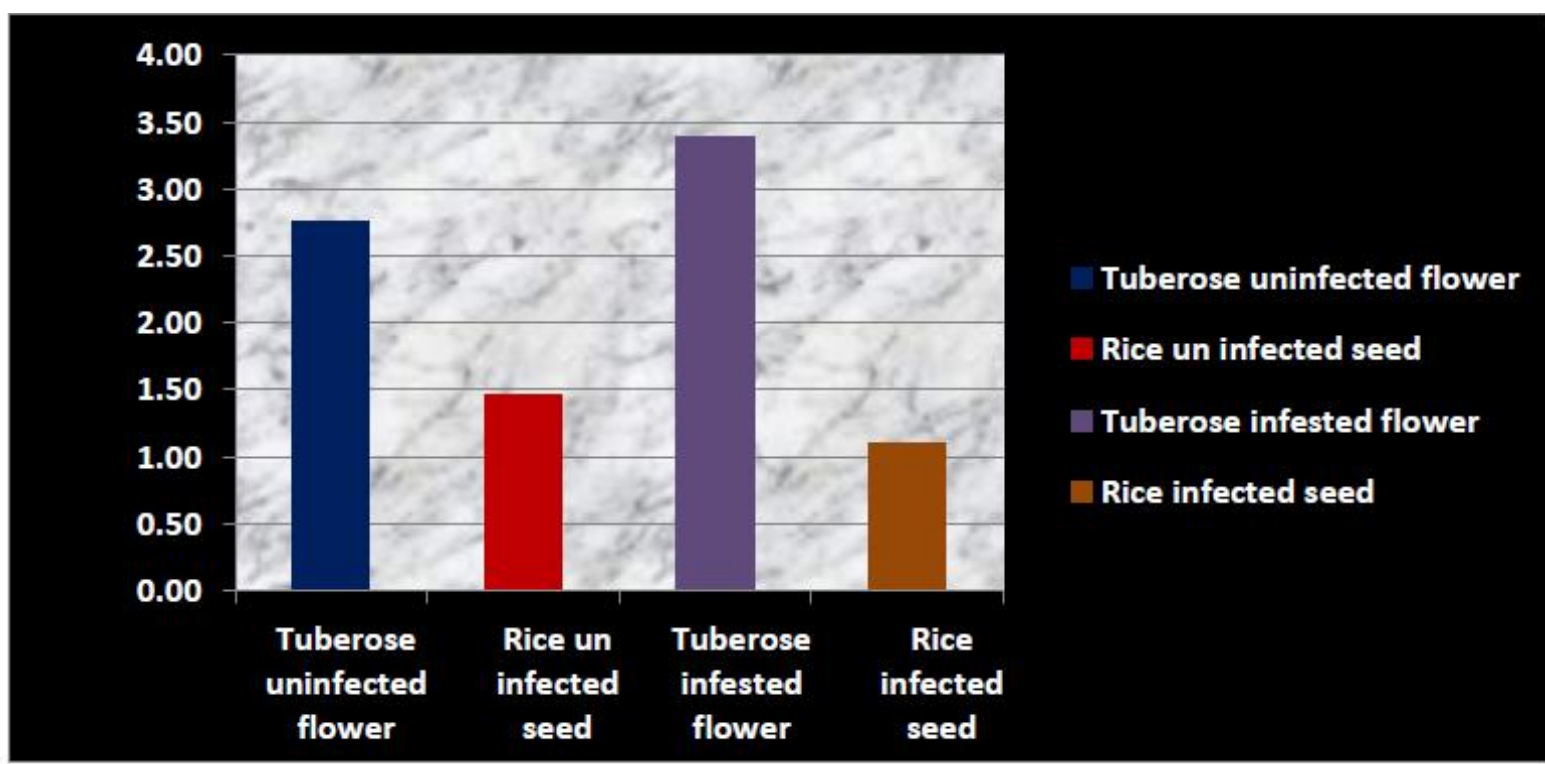

Fig.2 Percentage changes in protein content in uninfected and infected plants of tuberose (stalk) and rice (culm)

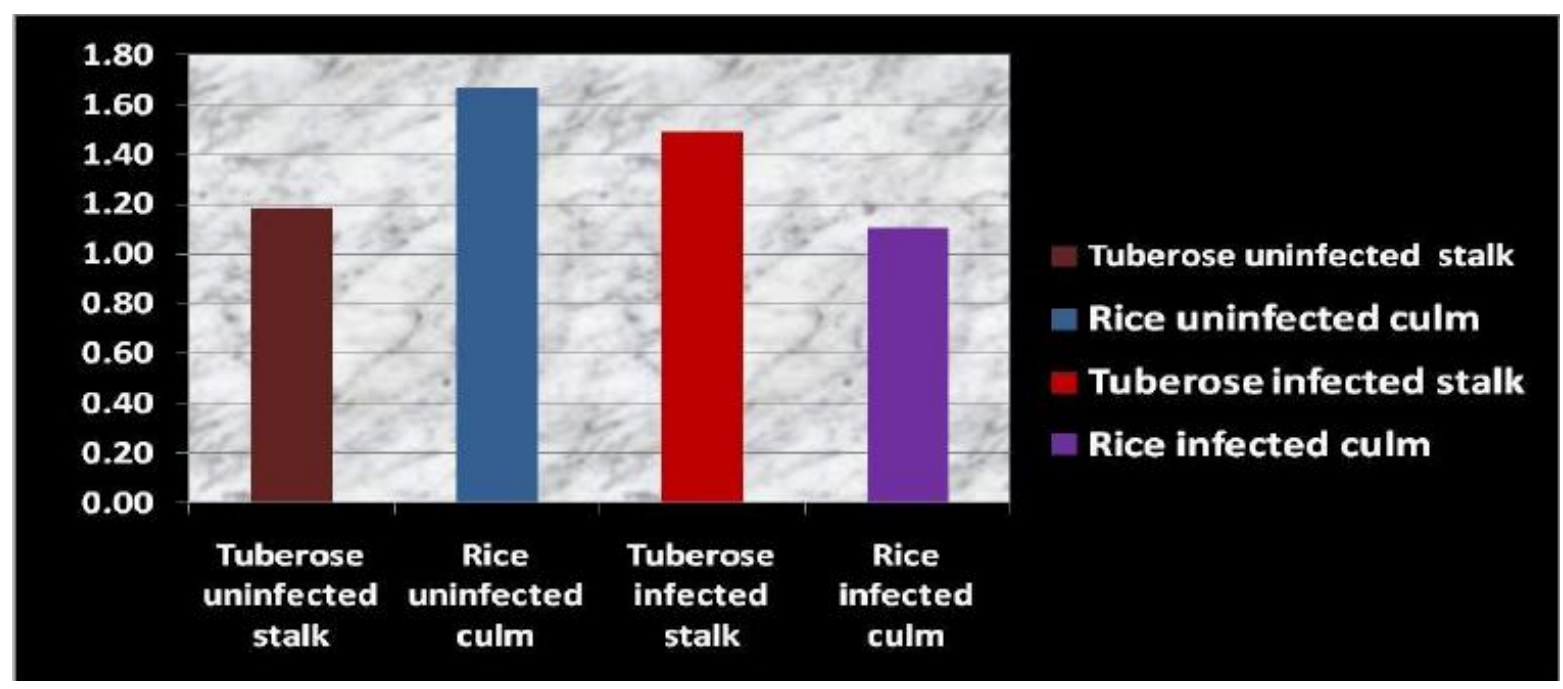


Fig.3 Percentage changes in silica content in uninfected and infected plants of tuberose (flower) and rice (seed)

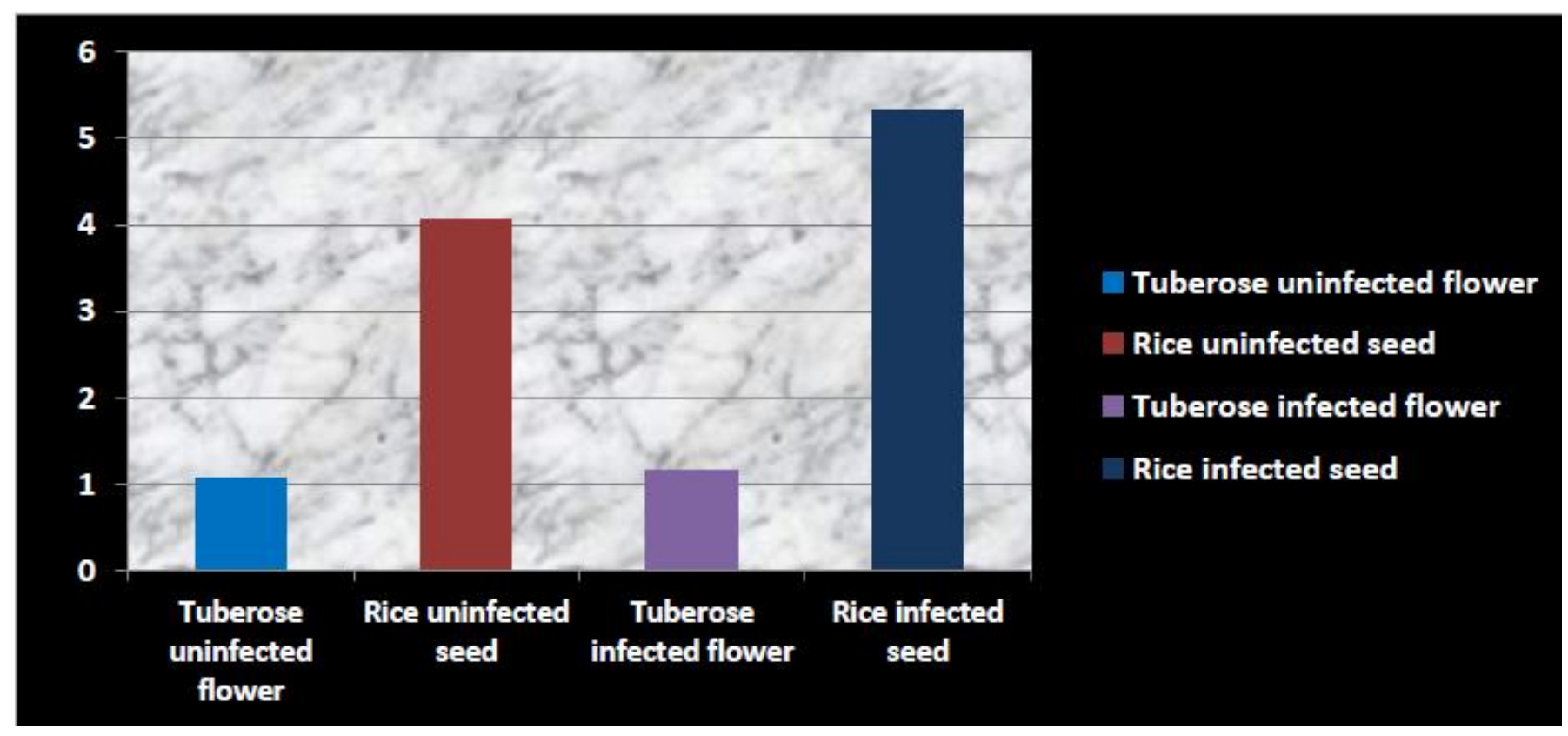

Fig.4 Percentage changes in silica content in uninfected and infected plants of tuberose (stalk) and rice (culm).

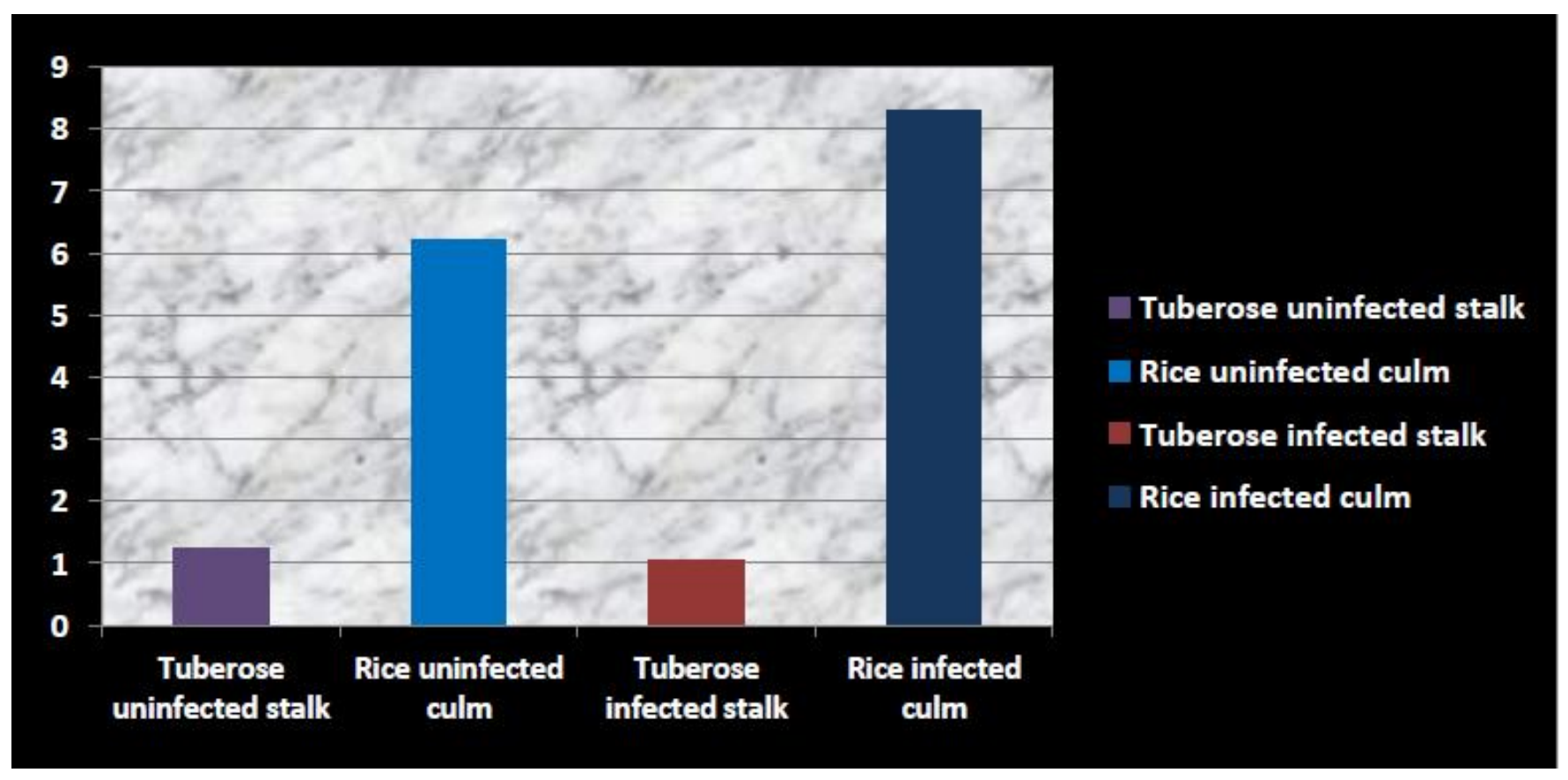


Fig.5 Percentage changes in carbohydrate content in uninfected plants of tuberose and rice anthers

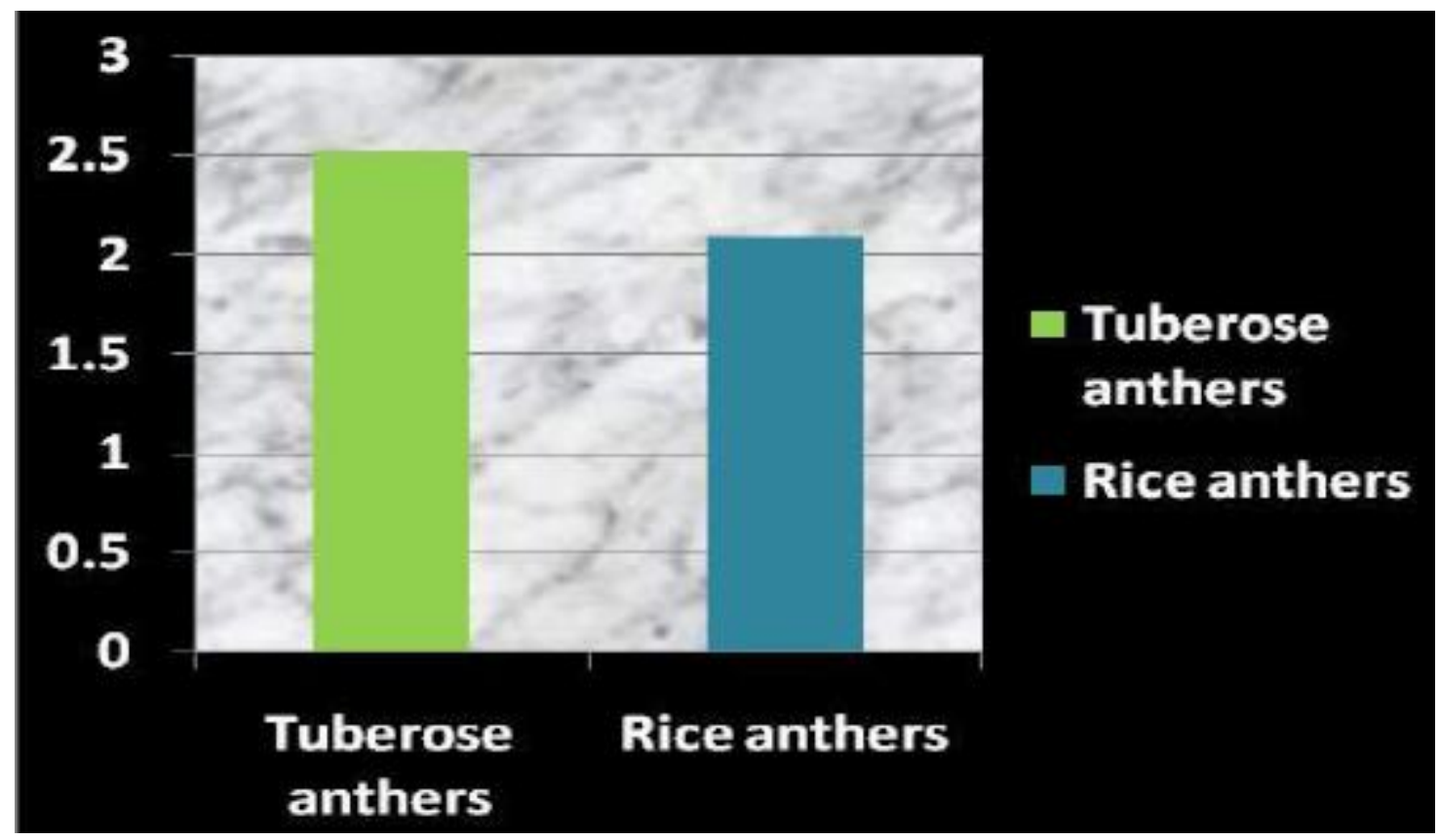

\section{Plant silica profile}

Silicon has generally not been considered essential for plant growth, although it is well recognized that many plants, particularly Poaceae, have substantial plant tissue concentrations of this element. Recently, however, the International Plant Nutrition Institute [IPNI] (2015), Georgia, USA has listed it as a "beneficial substance". Numerous studies have now established that silicon may alleviate both biotic and abiotic stress. Silicon confers resistance to herbivores via two described mechanisms: physical and biochemical/molecular. The reported relationships between soluble silicon and the jasmonic acid (JA) defense pathway, and JA and herbivore-induced plant volatiles (HIPVs) suggest that soluble silicon may enhance the production of HIPVs. Further, it is feasible that silicon uptake may affect protein expression (or modify proteins structurally) so that they can produce additional, or modify, the HIPV profile of plants. Rice exhibits the greatest uptake of silicic acid in the grass family. Silicon helps to strengthen cells of rice leaf, stem, and roots. Epidermal cells accumulate the most amount of silicon absorbed from the soil. Evaluation of preference/non preference of the foliar nematodes towards tuberose and rice on the basis of silica content was made randomly selected rice culms, seeds, tuberose stalks and flowers, irrespective of their ages in 20162017. The experimental findings revealed that the total silica content in uninfected rice seeds was higher $(4.06 \%)$ than that of healthy tuberose flowers $(1.06 \%)$ and was highest in infected seeds of rice $(5.3 \%)$ (Table 2 and Fig. 3). Silicon is deposited in the form of silica gel or biogenetic opal as amorphous $\mathrm{sio}_{2} \mathrm{nH}_{2} \mathrm{O}$ in cell walls and intercellular spaces of root and leaf cells as well as in bracts. Silicon also can be found in the form of monosilicic acid, colloidal silicic acid, or organo silicon compounds in plant tissues. Therefore, differential silicon contents also could have been a strong reason behind the inclination of preference to the tuberose by the foliar nematodes. 


\section{Plant total carbohydrate profile}

During flower growth, most of the sugar needs in developing reproductive organs. Following leaf or flower bud photosynthesis, carbohydrate are transported towards anthers through the filament (Keijzer et al., 1987). Sucrose is the main form of sugar transport in the plant (Lawrence and Mayne 1991) and was found to be the major form of carbohydrate in young filaments. The anther in the plant containing highest concentration of soluble sugars. In Oryza sativa, it reaches $2.5 \%$ of dry weight against a maximum of $0.05 \%$ in the other organs (Kawaguchi et al., 1996). The results on the total carbohydrate profile on uninfected rice and tuberose anthers unveiled that carbohydrate content was high in tuberose $(2.52 \%)$ than rice (2.09 $\%$ ) (Table 3 and Fig 5). Sugar elevations were shown to contribute substantially to enhance nematode development (Grundler et al., 1991) and have major nutritional value for the obligate parasites. This may be another good reason towards comparatively more affinity of the foliar nematode populations to tuberose than rice.

\section{Acknowledgement}

First and foremost I would like to thank the Almighty god for giving me this opportunity. I feel unfathomable euphoria to pronounce my Heartful veneration and gratitude to Dr. A. K. Mukhopadhyay, Professor, Department of agricultural Entomology, BCKV.I further extend my sincere gratitude to Prof. Md. Nasim ali, Department of Agricultural Biotechnology, Dr. D.K. Mishra, Department of Agricultural plant pathology, Prof. S.K. Pal, Department of Agricultural Soil Science, Prof. A.K. Basu, Department of seed science for providing their sincere guidance, keen interest, inestimable inspiration and valuable suggestions throughout the course of investigation. I would like to acknowledge the peoples who mean world to me, my family who supported me during my time here. Last but not least I want to thank all my friends who helped and encouraged me in conducting my research work from starting to end of work.

\section{References}

Dastur, J.F., 1936. A nematode disease of rice in the central proviness. Proceeding of the Indian Academy of Sciences. 4: 108 $-122$.

Grundler, F.M.W., Betka, M. and Wyss, U. 1991. Influence of changes in the nurse cell system (syncytium) on sex determination and development of the cyst nematode Heterodera schachtii: total amounts of proteins and amino acids. Phytopathology 81: 70-74.

Holtzman, O.V., 1968. A foliar disease of tuberose causer by Aphelenehoides beseyi. Plant Dis. Reptr. 52: 56.

Keijzer, C., Hoek, I. and Willemse, M. 1987. The processes of anther dehiscence and pollen dispersal III. The dehydration of the filament tip and the anther in three monocotyledonous species. New Phytologist. 106:281-287.

Khan, M.R., 2001. While tip nematode, Aphelenchoides besseyi inn ricetuberose cropping system. Proc. National Seminar on Frontier of Crop Management, Feb. 3. Sriniketan, Viswa Bharati, West Bengal, India. 142 - 143.

Lawrence, D. K., and Mayne, R. G. 1991. Plant Growth Regulators and Photosynthesis. Herbicides Elsevier Science, New York, 299-335.

Lowry, O.H., Rosebrough, N.J., Farr, A.L., and Randall, R.J. 1951. Protein measurement with the folin-phenol reagent. Journal of Biological Chemistry 193, 265-275.

Prabhu, M., Ramesh A. K. and Ponnuswami, V. 2008. Breeding for shoot and fruit 
borer resistance in brinjal. Asian $J$. publishing house Pvt. Ltd, New Hort., 3(2): 456- 459. Delhi.pp-198.

Rao, Y.S., Prassad, J.S. and Panwar, M.S. Southey, J.F., 1970. Laboratory methods for 1985 Nematode pest of rice in India. work with plant and soil nematodes. Non-insect pest and predator, 65-71.

Ravichandra, N.G., 2008. Textbook on Plant Nematology, I.K. International Technical Bulletin 2, Mins. Agr. Fish food. HMSO, London.

\section{How to cite this article:}

Nagulapalli Sneha Latha, Ajoy Kumar Mukhopadhyay, Nagamandla Ramya Sri, Nihal Ravindranath and Dhiren Chatterjee. 2017. Study on Relative Preferences of Foliar Nematode, Aphelenchoides besseyi Christie between Rice and Tuberose on Biochemical Factors. Int.J.Curr.Microbiol.App.Sci. 6(10): 1648-1656. doi: https://doi.org/10.20546/ijcmas.2017.610.199 